\title{
Is annual recharge coefficient a valid concept in arid and semi-arid regions?
}

\author{
Yiben Cheng ${ }^{1,2}$, Hongbin Zhan ${ }^{2}$, Wenbin Yang ${ }^{1}$, Hongzhong Dang ${ }^{1}$, and Wei $\mathrm{Li}^{1}$ \\ ${ }^{1}$ Institute of Desertification Studies, Chinese Academy of Forestry, Haidian District, Beijing 100093, China \\ ${ }^{2}$ Department of Geology and Geophysics, Texas A\&M University, College Station, TX 77843-3115, USA \\ Correspondence to: Yiben Cheng (chengyiben07@gmail.com) and Hongbin Zhan (zhan@geos.tamu.edu)
}

Received: 20 March 2017 - Discussion started: 25 April 2017

Revised: 30 August 2017 - Accepted: 7 September 2017 - Published: 6 October 2017

\begin{abstract}
Deep soil recharge (DSR) (at depth greater than $200 \mathrm{~cm}$ ) is an important part of water circulation in arid and semi-arid regions. Quantitative monitoring of DSR is of great importance to assess water resources and to study water balance in arid and semi-arid regions. This study used a typical bare land on the eastern margin of Mu Us Sandy Land in the Ordos Basin of China as an example to illustrate a new lysimeter method of measuring DSR to examine if the annual recharge coefficient is valid or not in the study site, where the annual recharge efficient is the ratio of annual DSR over annual total precipitation. Positioning monitoring was done on precipitation and DSR measurements underneath mobile sand dunes from 2013 to 2015 in the study area. Results showed that use of an annual recharge coefficient for estimating DSR in bare sand land in arid and semi-arid regions is questionable and could lead to considerable errors. It appeared that DSR in those regions was influenced by precipitation pattern and was closely correlated with spontaneous strong precipitation events (with precipitation greater than $10 \mathrm{~mm}$ ) other than the total precipitation. This study showed that as much as $42 \%$ of precipitation in a single strong precipitation event can be transformed into DSR. During the observation period, the maximum annual DSR could make up $24.33 \%$ of the annual precipitation. This study provided a reliable method of estimating DSR in sandy areas of arid and semi-arid regions, which is valuable for managing groundwater resources and ecological restoration in those regions. It also provided strong evidence that the annual recharge coefficient was invalid for calculating DSR in arid and semi-arid regions. This study shows that DSR is closely related to the strong precipitation events, rather than to the average annual precipitation, as well as the precipitation patterns.
\end{abstract}

\section{Introduction}

Recharge is an important source of groundwater budget and it is also a fundamental process that links the surface hydrological processes (e.g., precipitation), vadose zone process (e.g., infiltration and soil moisture dynamics), and the saturated zone process (e.g., groundwater flow) (Sanford, 2002; McWhorter and Sunada, 1977). How to accurately estimate recharge has remained a persistent challenge and an active research topic in the hydrological science community over many decades (Gee and Hillel, 1988; Scanlon, 2013; Sanford, 2002). It is generally accepted that recharge is correlated with precipitation in some fashions, and many studies adopt the concept of a recharge coefficient (Turkeltaub et al., 2015; Kalbus et al., 2006; Allocca et al., 2014), which is the ratio of the actual recharge to the precipitation, to estimate the recharge (Fiorillo et al., 2015; Allocca et al., 2014). The magnitude of such a recharge coefficient is controlled by a complex interplay of multiple factors such as moisture dynamics in the vadose zone (Schymanski et al., 2008), depth to water table, vegetation, etc., and the recharge coefficient is often regarded as a temporally invariant value at a given location (Fiorillo et al., 2015; Min et al., 2017; Vauclin et al., 1979). Specifically, it is assumed to be primarily controlled by the total precipitation and not too much by the temporal fluctuation of precipitation events (Hickel and Zhang, 2006; Acworth et al., 2016). In this study, we will challenge the concept of using a constant recharge coefficient to estimate the recharge in arid and semi-arid regions based on a multiyear field investigation. 
As water tables in many arid and semi-arid regions are relatively deep (greater than $2 \mathrm{~m}$ below ground surface) (Williams, 1999; Soylu et al., 2011), recharge in those regions is named deep soil recharge (DSR), which will be the concern of this study. DSR could ease the demand of sandfixing vegetation on moisture during extremely dry seasons (Zhang et al., 2001; Shou et al., 2017), and it reduces water deficit, sustains life activities, and helps the vegetation live through extreme droughts (Zhang et al., 2004). In this sense, DSR is an important factor of the water cycle in arid and semi-arid regions (Adolph, 1947), and it could also provide much-needed references for the stability analysis of sandfixing vegetation ( $\mathrm{Li}$ et al., 2004, 2014). In the following, we will briefly review the existing methods of estimating DSR.

In general, there are three methods of measuring DSR in arid and semi-arid regions. The first method is an empirical approach which assigns a constant recharge coefficient associated with a certain precipitation event (Allison et al., 1994; Jiménez-Martínez et al., 2010). The empirical approach is simple to use but it lacks a rigorous theoretical base, and the recharge coefficient has to be calibrated through a groundwater flow model in the region, which is often not available.

The second method is a modeling approach involving numerical models such as HYDRUS (Šimůnek et al., 2012), SWAT (Arnold et al., 2012), UNSATH (Fayer, 2000), SWIM (Krysanova et al., 2005), and SWAP (van Dam, 2000) to calculate DSR. Modeling is an efficient way to test different hypothetical scenarios and it may be used to predict DSR in the future if the model is calibrated carefully. Detailed water balance models can be used for irrigated agriculture, but they usually cannot predict evapotranspiration accurately, especially when plants suffer seasonal water stress and plant cover is sparse (Gee and Hillel, 1988). When recharge is estimated as residual in water balance models, it can cause miscalculation as much as an order of magnitude (Scanlon, 2013; Voeckler et al., 2014). When using soil water flow models with measured or estimated soil hydraulic conductivities and tension gradients, similar miscalculation can also occur (Nyman et al., 2014; Gee and Hillel, 1988). In addition, the modeling usually involves upscaling of parameter values over a spatially and temporally discretized mesh from measurements which are made on specific moments and locations. Such an upscaling process is not always easy to execute and it could sometimes lead to serious errors. This is particularly true for arid and semi-arid regions where most precipitation may be episodic (occurring in short and unpredictable events) (Modarres and da Silva, 2007; Zhou et al., 2016) and may be confined to restricted portions of the area (Gee and Hillel, 1988).

The third method includes a cluster of experimental techniques such as isotopic tracers (Klaus and McDonnell, 2013), water fluxes (Katz et al., 2016), and lysimeters (Scanlon, 2013). Among them, lysimeters are instruments that directly measure the hydrological cycle in infiltration, runoff, and evaporation. Generally, this instrument is located in an open observation field or as a controlled device, working either solely or in groups (Good et al., 2015). In a typical lysimeter, soil is filled into a column surrounded by impermeable lateral boundaries; thus, water can only enter or leave the column from upper or lower boundaries (Duncan et al., 2016; Fritzsche et al., 2016). A drainage system is usually placed at the bottom (Glenn et al., 2013). The depth of soil in the column depends on the experimental purpose. Experiments can be done with the same type of soil at different depths in a single column or in different columns but at the same depth. The soil surface can be cultivated with different crops or left as bare land. Observations can be recorded with weight or volume of water.

Application of above-mentioned methods for assessing DSR in arid and semi-arid regions has met a variety of challenges, primarily due to the fact that precipitation events often happen in the form of short pulses with highly variable intensity (Collins et al., 2014). The intermittent and unpredictable characteristics of precipitation events led to highly variable moisture and nutrient levels in the soils (Beatley, 1974; Huxman et al., 2004). It is unclear how the precipitation amount, time, and interval will affect the water moisture of arid and semi-arid regions, especially the change of deep soil water storage.

In this study, a new type of lysimeter is designed to accurately measure the amount of DSR in arid and semi-arid regions. With the help of a 3-year (2013-2015) field investigation with this new lysimeter, one can answer the following question: is the concept of an annual recharge coefficient valid or not for estimating DSR at a given location in arid and semi-arid regions? Before the introduction of this new type of lysimeter, it is necessary to briefly explain the challenges faced by the conventional lysimeter for studying DSR in arid and semi-arid regions.

\section{Design of the new lysimeter for DSR measurement}

\subsection{Problems with the conventional lysimeter methods in arid and semi-arid regions}

Lysimeters have been used to access the amount of water consumed by vegetation for more than 300 years (Howell et al., 1991). The type of lysimeter that is specifically designed to measure evapotranspiration (ET), called the precision-weighing lysimeter, has been developed within the past six decades. In order to satisfy different requirements and needs, there are various designs of weighing lysimeters, with surface areas ranging from 1.0 to over $29 \mathrm{~m}^{2}$ (Howell et al., 1991). The stored media mass and the type of scale such as diameter and height are factors on which the accuracy of ET measurement depends, and many lysimeters have accuracy better than $0.05 \mathrm{~mm}$ (Howell et al., 1991). Figure 1a shows the schematic diagram of a conventional lysimeter installation in the field. It is basically a weight meter of soil 
with an open upper boundary at ground surface and a perforated bottom boundary and impermeable vertical side walls. The typical depth of lysimeters varies from 0.2 to $2 \mathrm{~m}$ but is rarely greater than $2.5 \mathrm{~m}$ (Howell et al., 1991). The horizontal cross-section area is usually in the range of 1 to $29 \mathrm{~m}^{2}$. Precipitated water can freely infiltrate into the soil from the top, and downward flow of water at the bottom of the lysimeter is collected (through the perforation) as a function of time to calculate the recharge. Alternatively, the weight of combined water and soil inside the lysimeter can be accurately measured using a weight gauge to reflect any soil moisture change. Such information, combined with infiltration or evaporation at the surface, can yield the information of downward water flux at the depth of lysimeter.

The following issues deserve special attention when applying the conventional lysimeter for measuring recharge. Firstly, soil layers are inevitably disturbed when installing the instrument, so the result may not reflect the actual recharge in native (undisturbed) soils (Weihermüller et al., 2007). Secondly, the cost is too high to use multiple lysimeters to observe large-scale infiltration (Stessel and Murphy, 1992). Thirdly, when precipitation strength is relatively light and concentrated, a large lysimeter cannot sensitively and rapidly measure DSR (Goldhamer et al., 1999; Farahani et al., 2007). The conventional lysimeter often cannot answer the questions as to what soil layer different levels of precipitation can infiltrate and how much the infiltration amount is under different levels of precipitation (Gee and Hillel, 1988; Ogle and Reynolds, 2004).

The conventional lysimeter as shown in Fig. 1a may meet additional challenges when applied to arid and semi-arid regions. Firstly, the water table depths in arid and semi-arid regions may be much greater than the maximal depth of a conventional lysimeter $(2.5 \mathrm{~m})$. For instance, in Chagan Lake, southeast of Mu Us Sandy Land in the Ordos Basin of China, the water table depth was found to be greater than $4 \mathrm{~m}$. In the Gobi Desert, the water table was reported to be at least $2.8 \mathrm{~m}$ deep (Ma et al., 2009). Therefore, the infiltration measured at the base of a conventional lysimeter may not represent the actual recharge that eventually enters the groundwater system. Secondly, the measurement accuracy of lysimeter often declines for soils with deep plant roots because the depth of lysimeter installation is limited and it may be less than the depth of those roots at site, which by itself can be important pathways for water migration. Consequently, the measured recharge of such disturbed soil by lysimeter may not represent the in situ recharge of the native (undisturbed) soil.

To resolve the above-mentioned issues faced by the conventional lysimeter, a new type of lysimeter is designed with specific considerations of the unique precipitation patterns and soil characteristics in arid and semi-arid regions. This new lysimeter is illustrated schematically in Fig. $1 \mathrm{~b}$.
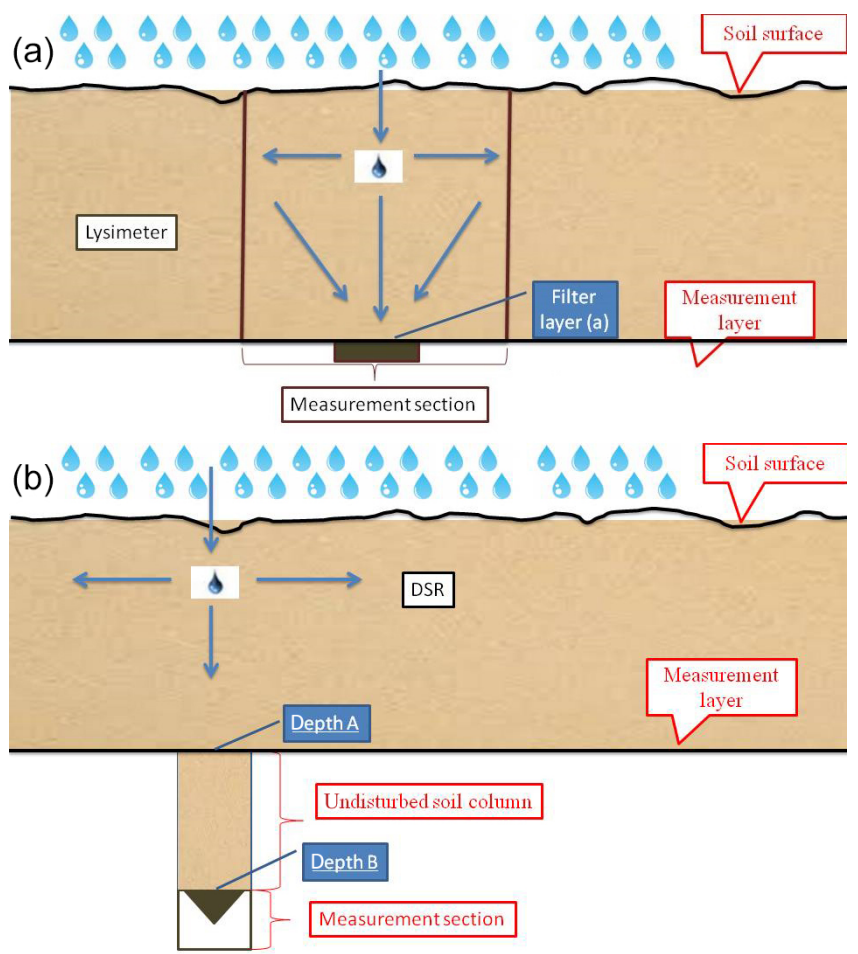

Figure 1. Schematic diagram of conventional lysimeter (a) and the new lysimeter (b).

\subsection{Design of a new lysimeter for measuring DSR in arid and semi-arid regions}

This new lysimeter has a few innovations (see Fig. 1b) that can be outlined as follows. Instead of setting the upper boundary of the lysimeter at ground surface, the new design has its upper boundary at a designed depth (denoted as depth A in Fig. 1b) where infiltration will be measured. A cylindrical container with a diameter of 20 to $40 \mathrm{~cm}$ with impermeable walls is installed from depth A downward to a deeper depth $\mathrm{B}$. The length of $\mathrm{AB}$ is determined according to the capillary rise of the in situ soil, which can be calculated using the average grain size of soils within AB. More specifically, the length of $\mathrm{AB}$ is greater than the capillary rise of soils within $\mathrm{AB}$ and it is usually greater than $0.6 \mathrm{~m}$ (Liu et al., 2014). At the soil surface, there is a device to measure the amount of the precipitation, and at the base of the instrument (depth B), a water collection device is used to measure the amount of water exit the base.

Before the measurement, one necessary preparation is to inject water from the top of the instrument at depth A using water pumps; the injection will stop until water starts to drip out from the base at depth B. One usually has to wait 10 days to allow the water profile in column $\mathrm{AB}$ to reach equilibrium. When water stops flowing out from depth $\mathrm{B}$, the soil water in the column is regarded as reaching its equilibrium state, in which the soil moisture at depth B reaches the maximum 
field capacity. Under such an equilibrium status, the amount of infiltration entering the upper surface of the lysimeter will be discharged (with the same amount) from the base of the lysimeter after a certain delay time.

The proposed new method has a few innovative features that have not been considered in previous studies. Firstly, it can measure DSR at any given layer of a multi-layer soil system using a single apparatus installed in the field. Secondly, continuous real-time measurements can be recorded over any given time period; thus, a time series of DSR can be obtained, which will be very useful to understand the soil water dynamics at sandy areas of arid and semi-arid regions. Thirdly, the apparatus is portable and easy to install; thus, a large amount of data can be collected in various locations of a study area using multiple lysimeters, and spatial recharge distribution can also be obtained straightforwardly. This method is field tested in arid and semi-arid sandy regions of western China. It provides key references for the evaluation of water resources, water balance, and the stability assessment of sandfixing vegetation in arid and semi-arid areas. It also provides data that are much needed for evaluating soil water contents and groundwater resources of those areas. An important feature of this new lysimeter is that it can provide reliable DSR data to examine the concept of the annual recharge coefficient when comparing with the precipitation data.

\section{Field testing of the new apparatus}

\subsection{Description of the study area}

Figure 2 shows the location of the study which is located in Ejin Horo Banner, on the eastern margin of $\mathrm{Mu}$ Us Sandy Land in the Ordos Basin of China (geographic location: $39^{\circ} 05^{\prime} \mathrm{N}, 109^{\circ} 36^{\prime} \mathrm{E}$; altitude: $1070-1556 \mathrm{~m}$ a.s.l.). The groundwater tables between dunes are $5.3-6.8 \mathrm{~m}$ below ground surface. The area is located in a semi-arid continental monsoon climate zone. Precipitation concentrates from July to September, with relatively concentrated rainstorms. The average annual precipitation from 1960 to 2010 is $296.01 \mathrm{~mm}$. The average annual temperature of this area is $6.5^{\circ} \mathrm{C}$, with about 151 days of frost-free season, $1809 \mathrm{~mm}$ total evaporation, an average of $2900 \mathrm{~h}$ of sunshine, and an average wind speed of $3.24 \mathrm{~m} \mathrm{~s}^{-1}$ (Wu and Ci, 2002; Karnieli et al., 2014). The study area is located in relatively gentle mobile dunes, and the soil type is Aeolian sandy soil.

In terms of geological structure, Mu Us Sandy Land is in the Ordos Basin, a large-scale syncline sedimentary basin with nearly north-south striking axis, and is of Mesozoic and Paleozoic ages. The basin covers an area of $640 \mathrm{~km}$ from north to south and $400 \mathrm{~km}$ from east to west. The axis of syncline is off west, and the east and west wings are asymmetric. The east wing is Monoclinic of westward tilt with a width of more than $300 \mathrm{~km}$. The west wing is made of many fault-fold belts striking along the north-south direc- tion and thrusting eastward with a width of less than $100 \mathrm{~km}$. The southern boundary of the basin is Weibei plateau uplift. The southern part of this plateau uplift is descending in a ladder shape with blocks to Fenwei rift-subsidence basin. The northern boundary of this basin is Yimeng plateau uplift, with a lack of Lower Paleozoic, and its edge fault is connected to the Hetao fault basin. The basement of the Ordos Basin is of Precambrian crystalline metamorphic rocks.

Deposited in the basin are, in turn, Lower Paleozoic carbonate rocks, Upper Paleozoic-Mesozoic clastic rocks, and Cenozoic sedimentary rocks with a total depth of more than $6000 \mathrm{~m}$. The discontinuous Cenozoic sediment is on top of the Mesozoic and Paleozoic layers, mainly of the Quaternary and partially of the Tertiary sediments. The Quaternary layer is mainly made of Aeolian sand and loess. Generally divided by a line along the Great Wall, the northwest land surface is mainly covered by wind-blown sand layers of varying thickness and a 40-120 m thick layer of alluvial lacustrine; the southeast land surface is mainly covered by loess with various thickness from tens of meters to more than $200 \mathrm{~m}$. Below the loess layers, there is Tertiary Pliocene mud rock with thickness of a few meters to tens of meters.

The hydrostratigraphic units of the Ordos Basin are quite complex, consisting of multiple connected aquifers. Following the order from bottom to top, the multiple aquifers are primarily made from various rock types of a karst aquifer consisting of Precambrian and Ordovician limestone, a fractured aquifer consisting of Carboniferous and Jurassic clastic rocks, a porous-fractured aquifer of Cretaceous clastic rocks, and a porous aquifer consisting of unconsolidated Cenozoic and Quaternary sediments. Generally speaking, Mu Us Sandy Land has relatively rich groundwater resources. The shallow groundwater reservoir is estimated to hold about 120.3 billion metric tons of freshwater. Groundwater is mainly recharged by precipitation with an annual average recharge amount of 1.4 billion metric tons. Fine sands are the dominating sediments observed in the experimental site. In the upper $200 \mathrm{~cm}$ soil layer in the experiment area, the percentage of fine sand $(0.5-0.1 \mathrm{~mm})$ is $88.56,77.88,88.23$, $88.89,90.28,83.90$, and $84.21 \%$ at depths of $0,10,30,60$, 90,150 , and $200 \mathrm{~cm}$, respectively. The rest of the soils are primarily coarse sands. It is evident that the soil at the upper $200 \mathrm{~cm}$ is relatively homogeneous.

\subsection{Statistical analysis of data}

Research on the relationship between precipitation and DSR of bare sand land in arid and semi-arid regions is beneficial to understand the soil water dynamics of those regions. Because vegetation is absent, complexity related to transpiration process by plants is not a concern. Based on two time series of real-time data of precipitation and DSR, one can examine the relationship between DSR and precipitation. This study can serve as a basis for further study of DSR in semi-fixed and fixed sand lands with different fractional vegetation covers. 

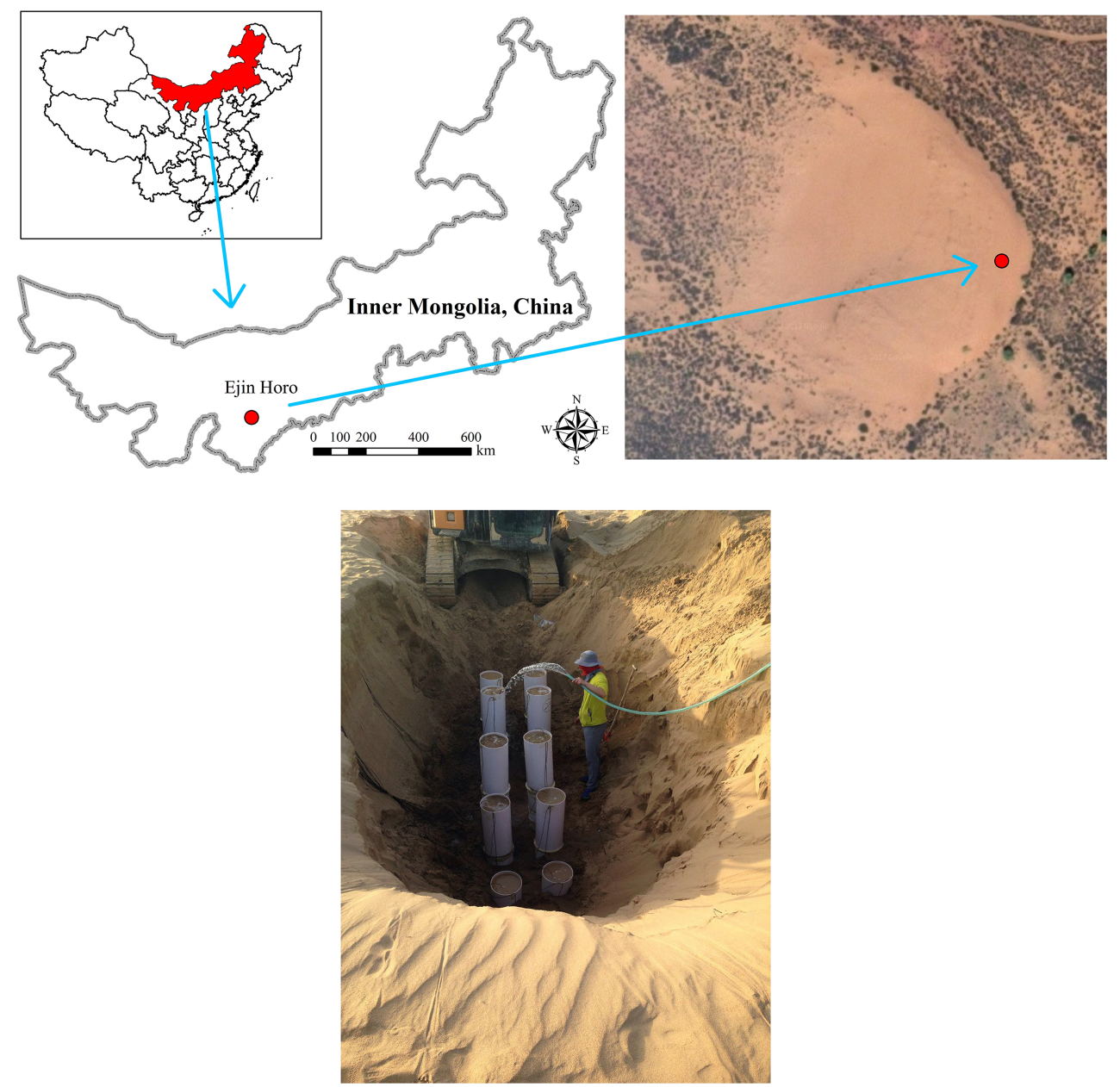

Figure 2. Geographic location of the experimental area.

On 1 September 2012, a mobile sand dune within the study site was set as the monitoring plot (geographic location: $39^{\circ} 05^{\prime} \mathrm{N}, 109^{\circ} 36^{\prime} \mathrm{E}$; altitude: $1310 \mathrm{~m}$ ) with the upper $300 \mathrm{~cm}$ soil profile excavated. The lysimeter as shown in Fig. 1b was installed following the procedure described in Sect. 2.2 and then backfilled using the excavated soil. Infiltration passing through the upper $200 \mathrm{~cm}$ depth is generally regarded as DSR in this study. It is worthwhile to point out that some other investigators may use a more or less different depth threshold for defining DSR. For instance, Zhang et al. (2008) used $140 \mathrm{~cm}$ instead of $200 \mathrm{~cm}$ depth as the threshold to define DSR. It was found that the water table depth was greater than $5 \mathrm{~m}$ in 2012-2015 at the study site, so its influence on DSR was negligible. A precipitation sensor (AV-3665R, AVALON, USA; precision: $0.2 \mathrm{~mm}$ ) was placed above ground at the site. A data acquisitor (CR200X, Campbell, USA) was used to record DSR, of which DSR data were recorded every hour, and the precipitation data were recorded every half hour. In order to avoid the effect of freeze-and-thaw action, the experiment was conducted be- tween 1 April 2013 and 30 November 2015. During such a 3year period, no runoff occured at the studied area.

The statistics of precipitation and DSR are shown in Table 1 , which reveals that there is an obvious difference of precipitation at the experimental plot from 2013 to 2015 . The annual precipitation is $83 \mathrm{~mm}$ in $2013,205.6 \mathrm{~mm}$ in 2014 , and $186.4 \mathrm{~mm}$ in 2015 . This is to say that the annual precipitation in 2014 and 2015 was 2.48 and 2.25 times that in 2013, respectively. Such a dramatic fluctuation and uneven distribution of annual precipitation is typical of arid and semi-arid regions. The corresponding annual DSR is $20.2 \mathrm{~mm}$ in 2013 , $20.6 \mathrm{~mm}$ in 2014, and $9.2 \mathrm{~mm}$ in 2015. This is to say that the annual DSR values in 2014 and 2015 are 1.02 and 0.46 of that in 2013. The annual DSR/precipitation ratios (or the socalled annual recharge coefficients) for 2013, 2014, and 2015 are $24.33,10$, and $4.94 \%$, respectively.

It appears that there is no clear correlation between the annual DSR and the annual precipitation according to the data of 2013-2015. In another words, use of the annual recharge coefficient for the study site becomes questionable as such 
Table 1. The annual precipitation-DSR relationship from 2013 to 2015.

\begin{tabular}{rrrr}
\hline Year & $\begin{array}{r}\text { Precipitation } \\
(\mathrm{mm})\end{array}$ & $\begin{array}{r}\text { DSR } \\
(\mathrm{mm})\end{array}$ & $\begin{array}{r}\text { DSR/precipitation } \\
\times 100 \%\end{array}$ \\
\hline 2013 & 83 & 20.2 & $24.33 \%$ \\
2014 & 205.6 & 20.6 & $10 \%$ \\
2015 & 186.4 & 9.2 & $4.94 \%$ \\
\hline
\end{tabular}

a coefficient implies that there is a close correlation between the annual DSR and the annual precipitation, which is not supported by the data of 2013-2015 here. Therefore, we will scrutinize the precipitation pattern and intensity more closely to decipher the connection of precipitation and DSR in the following.

\subsubsection{The relationship between precipitation pattern and DSR}

Research on bare sandy soil water dynamic processes usually focuses on temporal and vertical differences (Ritsema and Dekker, 1994; Postma et al., 1991). In terms of temporal soil moisture variation over an annual cycle, the process could be divided into soil moisture replenishment, depletion, and relatively stable periods. In terms of vertical soil moisture variation, soil water content usually first increases with depth and then decreases based on an interplay of mutual infiltration and evaporation processes. In general, soil could be divided as a surface dry sand layer, a layer with drastic moisture change, and a layer with relatively stable moisture content. Specifically, the soil deeper than $160 \mathrm{~cm}$ in arid and semiarid regions would have a relatively stable moisture content. This is because of two reasons. Firstly, soil water will not be uptaken to the surface by capillary force at such depths; secondly, ground water table in arid and semi-arid regions is usually much lower than $160 \mathrm{~cm}$.

In our study site, 2013 is an especially dry year with only $83 \mathrm{~mm}$ precipitation compared to $296.01 \mathrm{~mm}$ of average annual rainfall calculated over a period from 1960 to 2010 . The precipitation and DSR patterns of 2013 are shown in Fig. 3. The measurement accuracy of the lysimeter is $0.2 \mathrm{~mm}$. During the observation period from 1 April to 30 November, there are 25 total recorded precipitation events, mostly concentrated in the period from May to August. There is a one-time strongest precipitation event with a $24 \mathrm{~h}$ precipitation amount reaching $32 \mathrm{~mm}$ on 3 August. The DSR correlated to this event can be identified from 21 September to 30 November and reaches $17.2 \mathrm{~mm}$. The delay time from the precipitation event to the start of DSR is approximately 48 days. The DSR/precipitation ratio for this particular event is as high as $53.75 \%$. Such a DSR/precipitation ratio appears to be the highest in 2013. It is notable that although the strongest precipitation event on 3 August contributes the greatest to DSR observed from 21 September to 30 Novem- ber, a few precipitation events with amount of $6.6 \mathrm{~mm}$ prior to this strongest precipitation event also contribute a minor part for DSR from 27 July to 1 August. It is also notable that the $\mathrm{DSR} /$ precipitation ratio for the strongest precipitation event is substantially higher than the average annual recharge coefficient of $24.33 \%$ in 2013. This leads to the conclusion that DSR is closely related to the strong precipitation events rather than to the average annual precipitation.

In 2014, the annual precipitation is $205.6 \mathrm{~mm}$, and DSR is $20.6 \mathrm{~mm}$, leading to a $10 \%$ annual average recharge coefficient, which is less than half of that in 2013. As shown in Fig. 4, the frequency of precipitation events in 2014 is obviously higher than that of 2013. From 1 April to 30 November, there are total 68 instances of precipitation events, compared to 41 instances in 2013. Furthermore, the precipitation distribution in 2014 is more uniform than that in 2013. Specifically, precipitation events are concentrated in the period from June to August, with the highest $24 \mathrm{~h}$ accumulative precipitation of $15 \mathrm{~mm}$ on 30 July. As shown in Fig. 4, recorded DSR data cover a period from 1 April to 30 November, and the maximum DSR occurs on 1 October. Because the experimental plot is located in a transition zone between arid and semi-arid regions, summer evaporation is strong, leading to relatively less DSR during the summer season. During the period from 1 September to 30 November, atmospheric temperature drops and sunshine duration becomes shorter, which results in less surface evaporation and greater DSR during this period. Compared to 2013, there are more summer precipitation events in 2014 . That is one reason why precipitation in $2014(205.6 \mathrm{~mm})$ is greater than $2013(83 \mathrm{~mm})$ but the overall DSR in 2014 is less than that in 2013.

The strongest single-day precipitation in 2014 is $15 \mathrm{~mm}$ (occurring on 30 July), which is less than half of the strongest single-day precipitation event of $32 \mathrm{~mm}$ that occurred in 2013 (3 August); annual DSR/precipitation ratio is $24.33 \%$ in 2013 but drops to $10 \%$ in 2014. This once again supports the conclusion that the strong precipitation events rather than the average annual precipitation are mostly responsible for the average annual DSR. This is the other reason why precipitation in $2014(205.6 \mathrm{~mm})$ is greater than that in 2013 (83 mm) but the overall DSR in 2014 is less than that in 2013.

As shown in Fig. 5, the total annual precipitation of 2015 is $186.4 \mathrm{~mm}$, and DSR is $9.2 \mathrm{~mm}$, leading to a $4.94 \%$ annual average recharge coefficient, which is significantly smaller than that of $2013(24.33 \%)$ and $2014(10 \%)$. There are total 66 observable precipitation events in 2015. Such precipitation events are mostly concentrated from 4 April to 6 July, with a total precipitation of $155 \mathrm{~mm}$ during this period, which represents $83.15 \%$ of the total precipitation in 2015 . The measured DSR from 4 April to 6 July is only $7 \mathrm{~mm}$, representing $77.78 \%$ of the total DSR in 2015. Throughout 2015, the two strongest precipitation events happen on 4 April and 5 June; both $24 \mathrm{~h}$ precipitation events reach $17.2 \mathrm{~mm}$. We observe a single-day DSR peak of $0.8 \mathrm{~mm}, 36$ days after 4 April, one of the two greatest single-day DSR values ob- 

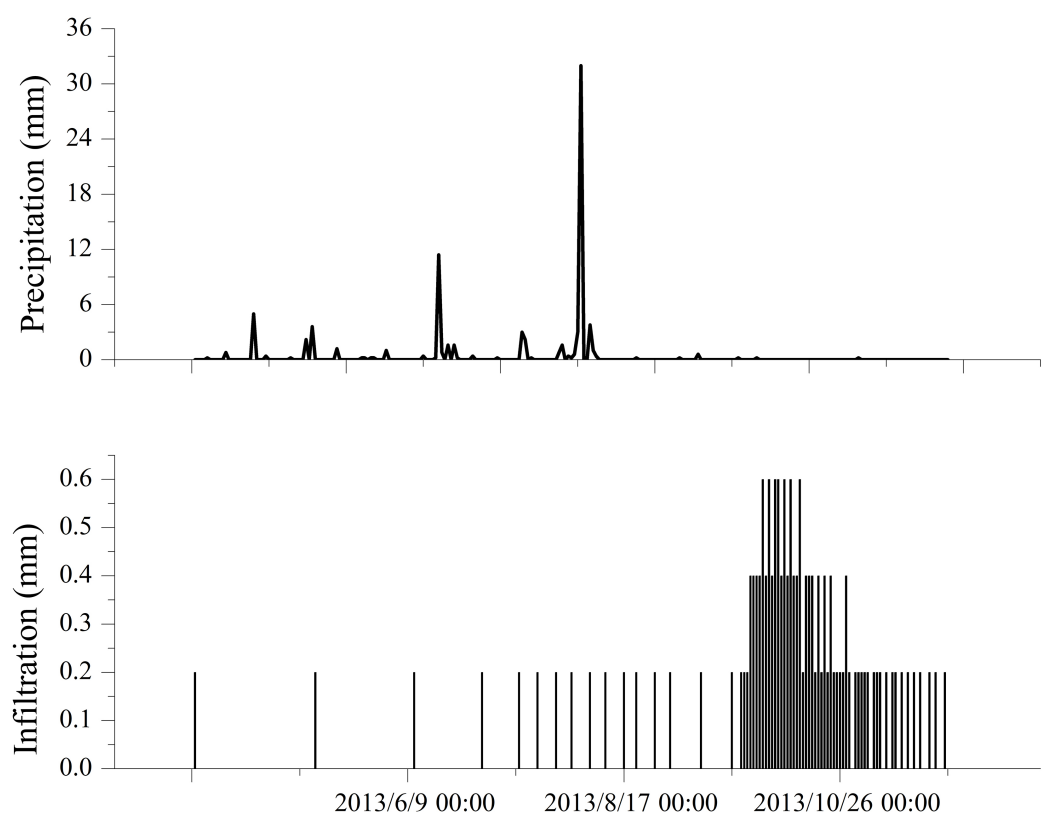

Figure 3. Precipitation and DSR patterns in 2013.
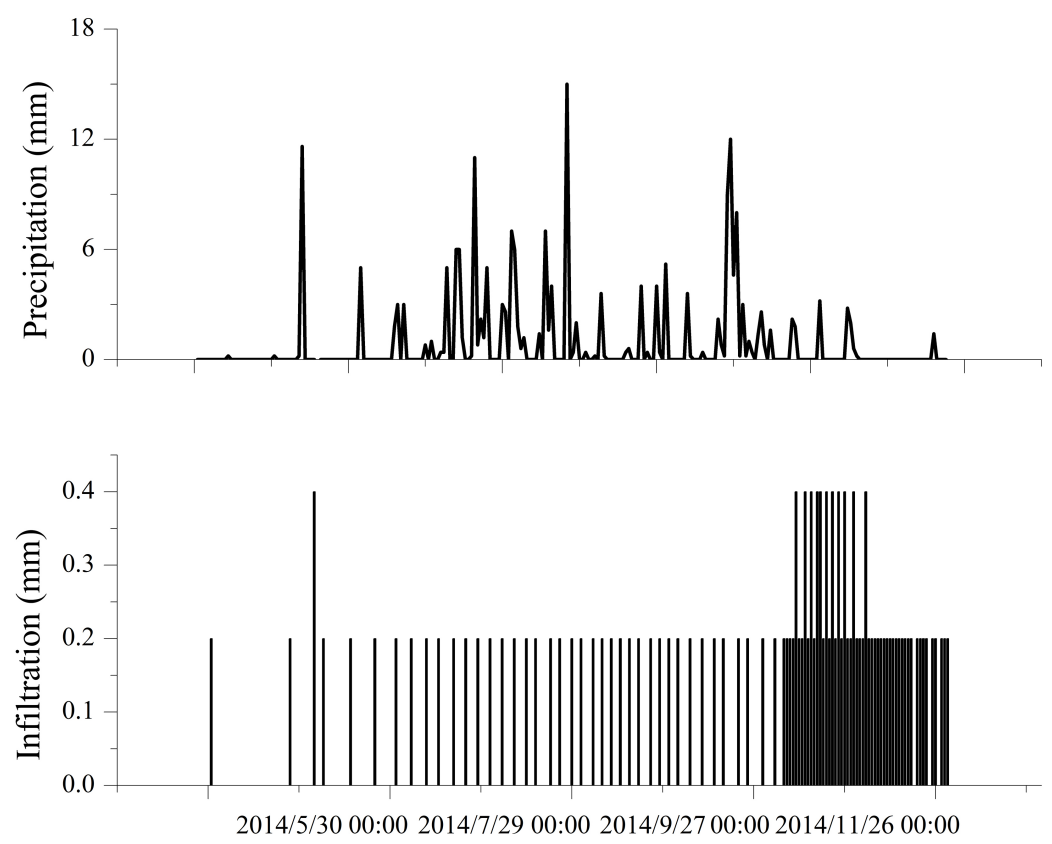

Figure 4. Precipitation and DSR patterns in 2014.

served in 2015, but no peak value of DSR response to the strong precipitation on 5 June. As explained before, summer stronger evaporation leads to relatively less DSR during the summer season compared with other seasons. The third greatest precipitation is $16.8 \mathrm{~mm}$ on 5 October, which leads to a peak value of $0.8 \mathrm{~mm}$ of DSR on 21 October, with a 16-day delay time. If comparing the precipitation events that occurred on 4 April $(17.2 \mathrm{~mm})$ and 5 October $(16.8 \mathrm{~mm})$, one can see that these two precipitation events are similar in strength (17.2 $\mathrm{mm}$ for 4 April and $16.8 \mathrm{~mm}$ for 5 October) but different in the DSR delay time (36 days for 4 April and 16 days for 5 October). When comparing two precipitation events which are similar in strength but different in the DSR delay time, temperature is the most likely factor responsible for such delay, so this leads to a conclusion that temperature influences the DSR rate. To investigate how the soil tem- 

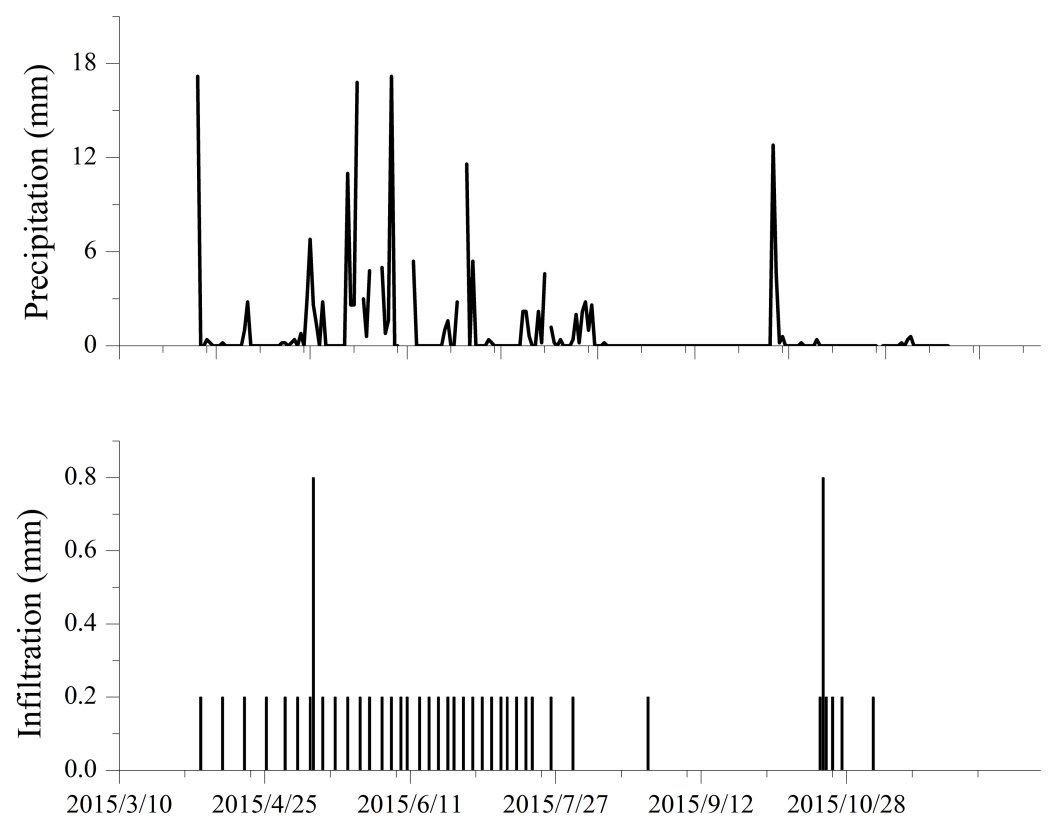

Figure 5. Precipitation and DSR patterns in 2015.

perature affects the DSR rate, further field experiments are needed in the future study.

\subsubsection{Relationship between precipitation intensity and DSR}

Based on observational data and analysis in Sect. 3.2.1, one can see that precipitation intensity, to some extent, influences DSR. For the sake of illustration, the precipitation intensity for bare sand land is roughly classified into light, moderate, and strong events with precipitation amounts less than $6 \mathrm{~mm}$, between 6 and $10 \mathrm{~mm}$, and greater than $10 \mathrm{~mm}$, respectively. In general, light precipitation rarely can reach the soil zone deeper than $40 \mathrm{~cm}$ because of evaporation; thus, it makes almost no contribution to DSR (Zhang et al., 2016). Such a classification may be revised under different vegetation-covering conditions in different regions (Kosmas et al., 2000).

According to this classification, statistics of moderate to strong precipitation events and their percentage shares in the annual precipitation from 2013 to 2015 are shown in Table 2. In 2013, there are only two precipitation events with intensity greater than $6 \mathrm{~mm}$. The total amount of these two precipitation events is $43.4 \mathrm{~mm}$, which represents $52.29 \%$ of the annual precipitation in 2013. In 2014, there are 11 precipitation events with intensity greater than $6 \mathrm{~mm}$, much more frequent than in 2013 ( 2 events) and moderately more frequent than that of 2015 ( 8 events). The total moderate-to-strong precipitation in 2014 is $98.6 \mathrm{~mm}$, representing $47.96 \%$ of the annual precipitation in 2014. In 2015, there are eight precipitation events with intensity greater than $6 \mathrm{~mm}$, accounting for $53.54 \%$ of the annual precipitation in 2015 .
Among these 3 years, 2015 has the largest percentage of moderate-to-strong precipitation over the annual precipitation. However, in this same year, one has seen the smallest ratio of annual DSR/precipitation ratio or annual recharge coefficient (see Table 1). This implies that the annual DSR does not seem to be positively correlated to the annual total precipitation. This finding has a few profound consequences. It basically states that assigning a constant annual recharge coefficient for a particular soil regardless of precipitation patterns is not a good practice, because annual DSR is not always proportional to the total annual precipitation. Instead, it appears to be more closely related to individual precipitation events stronger than $10 \mathrm{~mm}$.

Table 3 lists the number of strong precipitation (with amount greater than $10 \mathrm{~mm}$ ) and also the strongest precipitation amount for 2013, 2014, and 2015. In 2013, there are only two strong precipitation events, but the maximum single-day precipitation amount reaches $32 \mathrm{~mm}$ (3 August). The accumulative strong precipitation of 2013 is $43.4 \mathrm{~mm}$, which is $52.28 \%$ of the annual precipitation in 2013. In 2014, there are four strong precipitation events, and the maximum singleday precipitation amount is $15 \mathrm{~mm}$. The accumulative strong precipitation of 2014 is $49.6 \mathrm{~mm}$, which is $24.12 \%$ of the annual precipitation in 2014. In 2015, there are six strong precipitation events, and the maximum single-day precipitation amount is $17.2 \mathrm{~mm}$. The accumulative strong precipitation of 2015 is $86.6 \mathrm{~mm}$, which represents $46.46 \%$ of the annual precipitation in 2015 . The annual DSR vs. annual precipitation ratios are 24.33, 10, and 4.94\% for 2013, 2014, and 2015, respectively. 
Table 2. Percentage of valid precipitation in total precipitation amount.

\begin{tabular}{rrrr}
\hline Year & $\begin{array}{r}\text { Number of } \\
\text { precipitation }>6 \mathrm{~mm} \\
(24 \mathrm{~h} \text { cumulative })\end{array}$ & $\begin{array}{r}\text { Amount of } \\
\text { precipitation }>6 \mathrm{~mm} \\
(\mathrm{~mm})\end{array}$ & $\begin{array}{r}\text { Valid precipitation/ } \\
\text { annual precipitation } \\
(\%)\end{array}$ \\
\hline 2013 & 2 & 43.4 & 52.29 \\
2014 & 11 & 98.6 & 47.96 \\
2015 & 8 & 99.8 & 53.54 \\
\hline
\end{tabular}

Table 3. Interannual statistics of strong precipitation and its percentage in total annual precipitation amount.

\begin{tabular}{rrrrr}
\hline Year & $\begin{array}{r}\text { Number of strong } \\
\text { precipitation }\end{array}$ & $\begin{array}{r}\text { Maximum precipitation } \\
\text { event }(\mathrm{mm})\end{array}$ & $\begin{array}{r}\text { Annual DSR } \\
(\mathrm{mm})\end{array}$ & $\begin{array}{r}\text { Annual } \\
\text { DSR/annual } \\
\text { precipitation (\%) }\end{array}$ \\
\hline 2013 & 2 & 32 & 20.2 & 24.33 \\
2014 & 4 & 15 & 20.6 & 10 \\
2015 & 6 & 17.2 & 9.2 & 4.94 \\
\hline
\end{tabular}

As shown in Table 3, the strongest single-day precipitation (32 $\mathrm{mm}$ in 2013) appears to affect DSR the most in 2013. For 2014 and 2015, as the strongest precipitation events in these 2 years are significantly smaller than those in 2013. Such a positive correlation is particularly strong for 2013 which has the largest maximum precipitation event of $32 \mathrm{~mm}$, showing that the strong single-day precipitation affects DSR. This positive correlation is weaker for 2014 and 2015, which have moderate and somewhat similar maximum precipitation events (15 and $17.2 \mathrm{~mm}$, respectively). As shown in Figs. 4 and 5, precipitation patterns in 2014 and 2015 are quite different despite the fact that the maximum precipitation events are similar to each other. The precipitation in 2014 is somewhat uniformly distributed from April to November, while the precipitation in 2015 is mostly concentrated from May to June. This observation suggests that DSRs for these 2 years are related to the precipitation pattern as well as the precipitation strength. However, precisely quantifying such a correlation between DSR and the precipitation pattern and precipitation strength requires further investigations.

In summary, one may conclude that annual DSR in arid and semi-arid regions mainly relies on strong precipitation events, but the determination of the threshold for strong precipitation events that directly contribute to DSR is still unclear and requires further investigation.

Under the condition of continuous precipitation, it may be difficult to discretize precipitation into individual events. The following example illustrates a procedure to deal with this situation. As shown in Fig. 6, there is a 13-day continuous precipitation process in 2013 from 27 July to 8 August, and the accumulative precipitation is $43.8 \mathrm{~mm}$. The start of a continuous DSR distribution corresponding to this 13-day continuous precipitation event is observed 3 days after the end of this precipitation process, and the peak value of DSR occurs 46 days after the end of this precipitation process. The DSR distribution gradually recedes to zero around 78 days after the end of the precipitation process. The accumulative DSR amount over a 75-day period is $18.4 \mathrm{~mm}$. The ratio of the 75day cumulative DSR over the 13-day precipitation event is $42 \%$.

\section{Discussion}

This improved lysimeter is on the real-time dynamic monitoring of DSR, and it provides reliable evidence for an accurate evaluation of precipitation-related recharging capability of bare sand lands in arid and semi-arid regions. However, there are a number of issues that deserve further attention and require additional investigations in the future. The moisture evaporation, the soil absorption of moisture, and the water infiltration of post-evaporative redistribution are all very complex processes, especially in arid and semi-arid regions. It is sometimes difficult to clearly distinguish the amount of evaporation and DSR with conventional methods as outlined in the introduction. This study selects precipitation and infiltration data during the period from 1 April to 30 November, so the influence of freeze-thaw process during winter is avoided, and the experimental design and data analysis are simplified. For these reasons, the next steps should be a fullterm monitoring, systematic study on DSR, as well as a study on the soil temperature and daily temperature influences on DSR.

Although this experiment does not address the issue of soil temperature effect on DSR in great detail, the relationship between DSR and soil temperature is evident. In general, a higher temperature means a stronger evaporation demand and thus an often smaller DSR.

Through the analysis of this study, one can see that the use of an annual recharge coefficient for the study area is not 

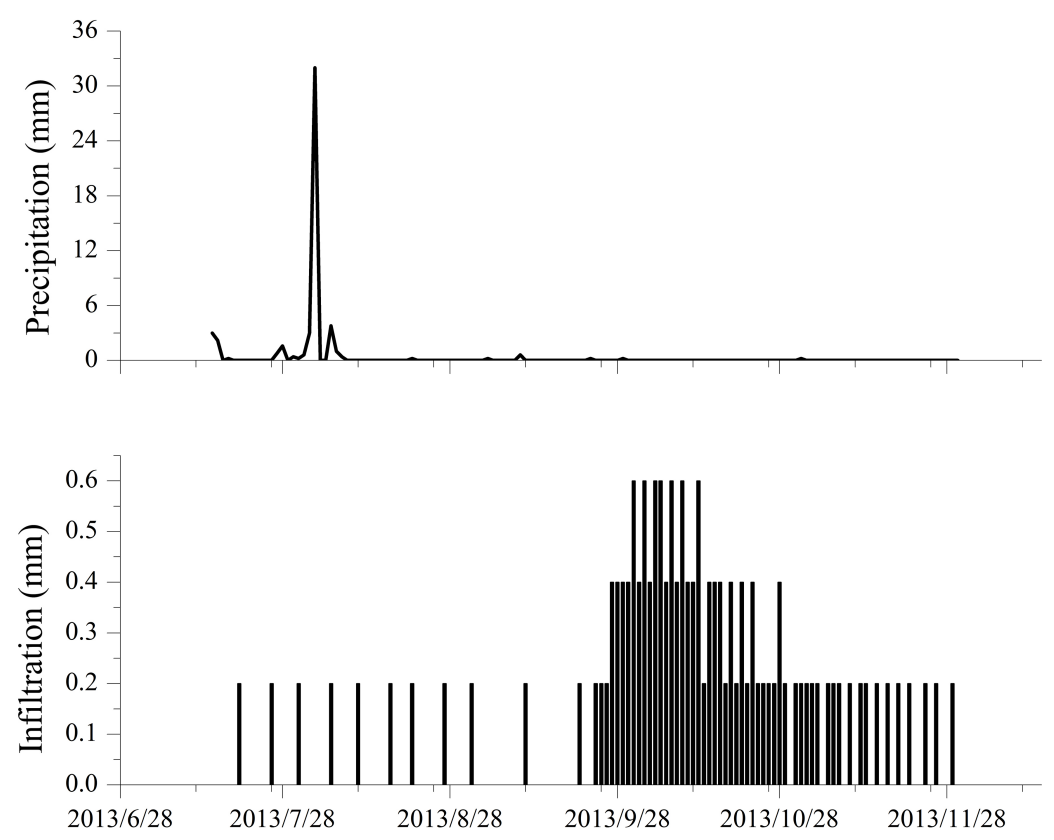

Figure 6. The single-day intensive precipitation contribution to DSR in 2013.

supported by the data collected from the new lysimeter, as the annual recharge is not positively correlated with the annual total precipitation. Instead, we find that the recharge is somewhat positively correlated with a few strong precipitation events (greater than $10 \mathrm{~mm}$ ), and is closely correlated with the strongest precipitation event (considerably greater than $10 \mathrm{~mm}$ ), as well as the precipitation patterns. It is probably reasonable to assign different weighting factors for different precipitation strengths to calculate DSR. However, the threshold to define a strong precipitation event that makes direct contribution to DSR is not precisely quantified, and this is a subject that should be investigated in more details in the future. The determination of weighting factors for different precipitation strengths is also a subject that requires further investigation.

This investigation is based on detailed analysis of precipitation and DSR data at the study site without involving modeling effort which certainly will be explored in the future as well. This study represents our first attempt of questioning the application of a recharge coefficient concept in arid and semi-arid regions.

\section{Conclusions}

This study uses a newly designed lysimeter to study three consecutive years (2013-2015) of DSR underneath bare sand land on the eastern margin of Mu Us Sandy Land in the Ordos Basin of China. The objective is to identify the characteristics of the DSR distribution and the factors affecting the DSR distribution. Specifically, we like to examine if the com- monly used recharge coefficient concept can be applied for arid and semi-arid regions such as the eastern margin of $\mathrm{Mu}$ Us Sandy Land of China. The following conclusions can be drawn from this study:

- The annual recharge coefficient concept is generally inapplicable for estimating DSR in the study site.

- Precipitation pattern, including precipitation intensity and precipitation season, significantly influences DSR.

- The temperature influences the DSR/precipitation ratio, which is lower in summer than in other seasons, given the similar precipitation intensity.

- DSR is not correlated with the annual precipitation. Instead, it is correlated with the strong precipitation (greater than $10 \mathrm{~mm}$ ) events at the site. However, quantitative determination of the thresholds for such strong precipitation events that make direct contributions to DSR is not entirely understood. Further investigation is needed on this subject.

Data availability. The data used in this study can be accessed by contacting the corresponding author directly.

Competing interests. The authors declare that they have no conflict of interest. 
Acknowledgements. This study was supported with research grants from the Ministry of Science and Technology of the People's Republic of China (2013CB429901).

Edited by: Graham Fogg

Reviewed by: two anonymous referees

\section{References}

Acworth, R. I., Rau, G. C., Cuthbert, M. O., Jensen, E., and Leggett, K.: Long-term spatio-temporal precipitation variability in arid-zone Australia and implications for groundwater recharge, Hydrogeol. J., 24, 905-921, 2016.

Adolph, E. F.: Physiology of Man in the Desert, Physiology of Man in the Desert, BMJ Publishing Group, Dept. of Physiology, University of Rochester, Interscience Publishers, Rochester, 1947.

Allison, G., Gee, G., and Tyler, S.: Vadose-zone techniques for estimating groundwater recharge in arid and semiarid regions, Soil Sci. Soc. Am. J., 58, 6-14, 1994.

Allocca, V., Manna, F., and De Vita, P.: Estimating annual groundwater recharge coefficient for karst aquifers of the southern Apennines (Italy), Hydrol. Earth Syst. Sci., 18, 803-817, https://doi.org/10.5194/hess-18-803-2014, 2014.

Arnold, J. G., Moriasi, D. N., Gassman, P. W., Abbaspour, K. C., White, M. J., Srinivasan, R., Santhi, C., Harmel, R., Van Griensven, A., and Van Liew, M. W.: SWAT: Model use, calibration, and validation, T. ASABE, 55, 1491-1508, 2012.

Beatley, J. C.: Phenological events and their environmental triggers in Mojave Desert ecosystems, Ecology, 55, 856-863, 1974.

Collins, S. L., Belnap, J., Grimm, N., Rudgers, J., Dahm, C. N., D’odorico, P., Litvak, M., Natvig, D., Peters, D. C., and Pockman, W.: A multiscale, hierarchical model of pulse dynamics in arid-land ecosystems, Annu. Rev. Ecol. Evol. S., 45, 397-419, 2014.

Duncan, M., Srinivasan, M., and McMillan, H.: Field measurement of groundwater recharge under irrigation in Canterbury, New Zealand, using drainage lysimeters, Agr. Water Manage., 166, 17-32, 2016.

Farahani, H., Howell, T., Shuttleworth, W., and Bausch, W.: Evapotranspiration: progress in measurement and modeling in agriculture, T. ASABE, 50, 1627-1638, 2007.

Fayer, M. J.: UNSAT-H version 3.0: Unsaturated soil water and heat flow model, Theory, user manual, and examples, Pacific Northwest National Laboratory, USA, https://www.osti.gov/scitech/ biblio/6820284 (last access: October 2017), 2000.

Fiorillo, F., Pagnozzi, M., and Ventafridda, G.: A model to simulate recharge processes of karst massifs, Hydrol. Process., 29, 23012314, 2015.

Fritzsche, A., Pagels, B., and Totsche, K. U.: The composition of mobile matter in a floodplain topsoil: a comparative study with soil columns and field lysimeters, J. Plant Nutr. Soil Sc., 179, 18-28, 2016.

Gee, G. W. and Hillel, D.: Groundwater recharge in arid regions: review and critique of estimation methods, Hydrol. Process., 2, 255-266, 1988.

Glenn, E. P., Anday, T., Chaturvedi, R., Martinez-Garcia, R., Pearlstein, S., Soliz, D., Nelson, S. G., and Felger, R. S.: Three halophytes for saline-water agriculture: an oilseed, a forage and a grain crop, Environ. Exp. Bot., 92, 110-121, 2013.

Goldhamer, D. A., Fereres, E., Mata, M., Girona, J., and Cohen, M. Sensitivity of continuous and discrete plant and soil water status monitoring in peach trees subjected to deficit irrigation, J. Am. Soc. Hortic. Sci., 124, 437-444, 1999.

Good, S. P., Noone, D., and Bowen, G.: Hydrologic connectivity constrains partitioning of global terrestrial water fluxes, Science, 349, 175-177, 2015.

Hickel, K. and Zhang, L.: Estimating the impact of rainfall seasonality on mean annual water balance using a top-down approach, J. Hydrol., 331, 409-424, 2006.

Howell, T. A., Schneider, A. D., and Jensen, M. E.: History of lysimeter design and use for evapotranspiration measurements, Lysimeters for Evapotranspiration and Environmental Measurements, 1-9, 1991.

Huxman, T. E., Snyder, K. A., Tissue, D., Leffler, A. J., Ogle, K., Pockman, W. T., Sandquist, D. R., Potts, D. L., and Schwinning, S.: Precipitation pulses and carbon fluxes in semiarid and arid ecosystems, Oecologia, 141, 254-268, 2004.

Jiménez-Martínez, J., Candela, L., Molinero, J., and Tamoh, K.: Groundwater recharge in irrigated semi-arid areas: quantitative hydrological modelling and sensitivity analysis, Hydrogeol. J., 18, 1811-1824, 2010

Kalbus, E., Reinstorf, F., and Schirmer, M.: Measuring methods for groundwater - surface water interactions: a review, Hydrol. Earth Syst. Sci., 10, 873-887, https://doi.org/10.5194/hess-10873-2006, 2006.

Karnieli, A., Qin, Z., Wu, B., Panov, N., and Yan, F.: Spatiotemporal dynamics of land-use and land-cover in the Mu Us sandy land, China, using the change vector analysis technique, Remote Sensing, 6, 9316-9339, 2014.

Katz, B. S., Stotler, R. L., Hirmas, D., Ludvigson, G., Smith, J. J., and Whittemore, D. O.: Geochemical Recharge Estimation and the Effects of a Declining Water Table, Vadose Zone J., 15, 15391663, https://doi.org/10.2136/vzj2016.04.0031, 2016.

Klaus, J. and McDonnell, J.: Hydrograph separation using stable isotopes: review and evaluation, J. Hydrol., 505, 47-64, 2013.

Kosmas, C., Danalatos, N., and Gerontidis, S.: The effect of land parameters on vegetation performance and degree of erosion under Mediterranean conditions, Catena, 40, 3-17, 2000.

Krysanova, V., Hattermann, F., and Wechsung, F.: Development of the ecohydrological model SWIM for regional impact studies and vulnerability assessment, Hydrol. Process., 19, 763-783, 2005.

Li, X., Zhang, Z., Tan, H., Gao, Y., Liu, L., and Wang, X.: Ecological restoration and recovery in the wind-blown sand hazard areas of northern China: relationship between soil water and carrying capacity for vegetation in the Tengger Desert, Science China, Life Sci., 57, 539, https://doi.org/10.1007/s11427-014-4633-2, 2014.

Li, X. R., Ma, F. Y., Xiao, H. L., Wang, X. P., and Kim, K. C.: Longterm effects of revegetation on soil water content of sand dunes in arid region of Northern China, J. Arid Environ., 57, 1-16, 2004.

Liu, Q., Yasufuku, N., Miao, J., and Ren, J.: An approach for quick estimation of maximum height of capillary rise, Soils Found., 54, 1241-1245, 2014.

Ma, J., Ding, Z., Edmunds, W. M., Gates, J. B., and Huang, T.: Limits to recharge of groundwater from Tibetan plateau to the 
Gobi desert, implications for water management in the mountain front, J. Hydrol., 364, 128-141, 2009.

McWhorter, D. B. and Sunada, D. K.: Ground-water hydrology and hydraulics, Water Resources Publication, Colorado, USA, 1977.

Min, L., Shen, Y., Pei, H., and Jing, B.: Characterizing deep vadose zone water movement and solute transport under typical irrigated cropland in the North China Plain, Hydrol. Process., 31, 14981509, https://doi.org/10.1002/hyp.11120, 2017.

Modarres, R. and da Silva, V. d. P. R.: Rainfall trends in arid and semi-arid regions of Iran, J. Arid Environ., 70, 344-355, 2007.

Nyman, P., Sheridan, G. J., Smith, H. G., and Lane, P. N.: Modeling the effects of surface storage, macropore flow and water repellency on infiltration after wildfire, J. Hydrol., 513, 301-313, 2014.

Ogle, K. and Reynolds, J. F.: Plant responses to precipitation in desert ecosystems: integrating functional types, pulses, thresholds, and delays, Oecologia, 141, 282-294, 2004.

Postma, D., Boesen, C., Kristiansen, H., and Larsen, F.: Nitrate reduction in an unconfined sandy aquifer: water chemistry, reduction processes, and geochemical modeling, Water Resour. Res., 27, 2027-2045, 1991.

Ritsema, C. J. and Dekker, L. W.: How water moves in a water repellent sandy soil: 2 . dynamics of fingered flow, Water Resour. Res., 30, 2519-2531, 1994.

Sanford, W.: Recharge and groundwater models: an overview, Hydrogeol. J., 10, 110-120, 2002.

Scanlon, B. R.: Evaluation of methods of estimating recharge in semiarid and arid regions in the southwestern US, in: Groundwater Recharge in a Desert Environment: The Southwestern United States, in: Water Science and Application Series, Vol. 9, edited by: Hogan, J. F., Phillips, F. M., and Scanlon, B. R., American Geophysical Union, 235-254, https://doi.org/10.1029/WS009, 2013.

Schymanski, S. J., Sivapalan, M., Roderick, M. L., Beringer, J., and Hutley, L. B.: An optimality-based model of the coupled soil moisture and root dynamics, Hydrol. Earth Syst. Sci., 12, 913932, https://doi.org/10.5194/hess-12-913-2008, 2008.

Shou, W., Musa, A., Liu, Z., Qian, J., Niu, C., and Guo, Y.: Rainfall partitioning characteristics of three typical sand-fixing shrubs in Horqin Sand Land, north-eastern China, Hydrol. Res., 48, 571583, https://doi.org/10.2166/nh.2016.177, 2017.

Šimůnek, J., Van Genuchten, M. T., and Šejna, M.: HYDRUS: Model use, calibration, and validation, T. ASABE, 55, 12611274, 2012.

Soylu, M. E., Istanbulluoglu, E., Lenters, J. D., and Wang, T.: Quantifying the impact of groundwater depth on evapotranspiration in a semi-arid grassland region, Hydrol. Earth Syst. Sci., 15, 787806, https://doi.org/10.5194/hess-15-787-2011, 2011.
Stessel, R. and Murphy, R.: A lysimeter study of the aerobic landfill concept, Waste Manage. Res., 10, 485-503, 1992.

Turkeltaub, T., Kurtzman, D., Bel, G., and Dahan, O.: Examination of groundwater recharge with a calibrated/validated flow model of the deep vadose zone, J. Hydrol., 522, 618-627, 2015.

van Dam, J. C.: Field-scale water flow and solute transport: SWAP model concepts, parameter estimation and case studies, Wageningen University, Wageningen, the Netherlands, 2000.

Vauclin, M., Khanji, D., and Vachaud, G.: Experimental and numerical study of a transient, twodimensional unsaturatedsaturated water table recharge problem, Water Resour. Res., 15, 10891101, 1979.

Voeckler, H. M., Allen, D. M., and Alila, Y.: Modeling coupled surface water-Groundwater processes in a small mountainous headwater catchment, J. Hydrol., 517, 1089-1106, 2014.

Weihermüller, L., Siemens, J., Deurer, M., Knoblauch, S., Rupp, H., Göttlein, A., and Pütz, T.: In situ soil water extraction: a review, J. Environ. Qual., 36, 1735-1748, 2007.

Williams, W. D.: Salinisation: a major threat to water resources in the arid and semiarid regions of the world, Lakes and Reservoirs: Research and Management, 4, 85-91, 1999.

Wu, B. and Ci, L. J.: Landscape change and desertification development in the Mu Us Sandland, Northern China, J. Arid Environ., 50, 429-444, 2002.

Zhang, J., Felzer, B. S., and Troy, T. J.: Extreme precipitation drives groundwater recharge: the Northern High Plains Aquifer, Central United States, Hydrol. Process., https://doi.org/10.1002/hyp.10664, in press, 2016.

Zhang, L., Dawes, W., and Walker, G.: Response of mean annual evapotranspiration to vegetation changes at catchment scale, Water Resour. Res., 37, 701-708, 2001.

Zhang, Y., Kendy, E., Qiang, Y., Changming, L., Yanjun, S., and Hongyong, S.: Effect of soil water deficit on evapotranspiration, crop yield, and water use efficiency in the North China Plain, Agr. Water Manage., 64, 107-122, 2004.

Zhang, Z.-S., Liu, L.-C., Li, X.-R., Zhang, J.-G., He, M.-Z., and Tan, H.-J.: Evaporation properties of a revegetated area of the Tengger Desert, North China, J. Arid Environ., 72, 964-973, 2008.

Zhou, J., Fu, B., Gao, G., Lü, Y., Liu, Y., Lü, N., and Wang, S.: Effects of precipitation and restoration vegetation on soil erosion in a semi-arid environment in the Loess Plateau, China, Catena, 137, 1-11, 2016. 